\title{
COVID-19 Pandemic: What can Nepal do to Curb the Potential Public Health Disaster?
}

\author{
Sujan Babu Marahatta ${ }^{1,2,3}$, Shishir Paudel ${ }^{1}$, Neeta Aryal $^{3}$
}

${ }^{1}$ Manmohan Memorial Institute of Health Sciences, Kathmandu, Nepal; ${ }^{2}$ Nepal Open University, Nepal

${ }^{3}$ Health Research Together Initiative-Nepal (Heart-Initiative), Kathmandu, Nepal

CORRESPONDENCE: Prof Dr Sujan B Marahatta; Email: sujanmarahatta@gmail.com ABSTRACT

COVID-19 caused by severe acute respiratory syndrome coronavirus 2 (SARS-CoV-2) has become the pandemic. Since its first report in late December from Wuhan, China, it has spread in 211 countries and has infected more than a million population claiming more than 81,000 lives until 7th April 2020. Although heterogeneous between countries, the recent trend shows that almost $10 \%$ of the infected persons are at the risk of death. The case-fatality has been reported to be at $2.3 \%$ in China, $7.2 \%$ in Italy, $1.73 \%$ in South Korea. One of the dreadful characteristics of the COVID-19 is that it is highly efficient at transmission from human to human. SARS-CoV-2 transmits from one human to another through respiratory droplets and close physical contact. Droplet transmission may also occur through fomites in the immediate environment around the infected person. Although there have been multiple studies and trials, no effective vaccines or anti-viral treatments have been effective to prevent or treat SARS-CoV-2 infection and can take another 12-18 months for the evidence to be generated. In this context, the only remained options would be to explore the epidemiological trend and learn from countries who have controlled the infection successfully. The early detection of cases and community containment have been some of the successful strategies. South Korea was able to lower the COVID-19 cases by an extensive and concerted community testing. The traditional strategies of isolation, quarantine, social distancing and community containment helped China to hold its level of infection after the second half of March 2020. With the increasing number of cases, Italy, the United State and the United Kingdom have increased their testing facilities. Germany, for instance, started mass testing and community surveillance quite early on (proactive community testing) reflected on its low fatality rate.

In Nepal by 5 April 2020, only 1,521 tests have been performed only among the suspected cases (a reactive testing method) who attend the hospital and so far 9 has been confirmed cases. Though the case was identified in January, the country-wide lockdown came into effect only on 24 March 2020. Based on the report provided by the Ministry of Health and Population, Nepal is trying its best to increase the number of isolation and quarantine facilities along with the provision of essential PPE. Nepal is at stage II (evidence of local transmission as opposed to imported cases only) of a pandemic but it is difficult to say how the disease is circulating in our population due to poor testing coverage and no proactive community testing. Current public health measures that are cost-effective, although not ideal would be to stringently follow social distancing. Social distance alone would be futile unless, other measures are in place that includes proactive community testing, providing essential medical equipment such as personal protective equipment (PPE), isolation and quarantine spaces, medical logistics such as infection control gears, and ICU facilities with adequate ventilators. While social distancing is the best measure, for now, community outreach for proactive testing with mobilization of community health workers and the use of technologies to inform the preventive measures and to dispel the fears, and rumors can be promising. Including the general public, health workers and policymakers require a strong collaborative platform to work together to consolidate the measures ahead to prevent the COVID-19 disaster in Nepal.

Keywords: COVID-19, SARS-CoV-2 pandemic, surveillance, social distancing

\section{Access this article Online}

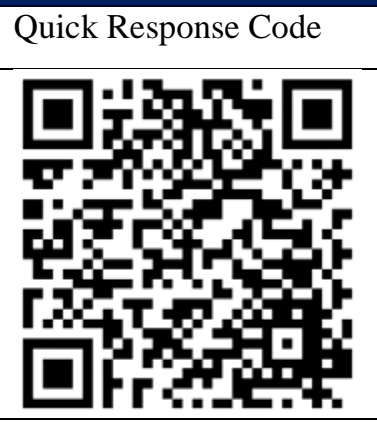

\section{Article Info.}

How to cite this article in Vancouver Style?

Marahatta SB, Paudel S, Aryal N. COVID-19 pandemic: What can Nepal do to Curb the Potential Public Health Disaster? Journal of Karnali Academy of Health Sciences 2020;3(1):1-14. Received: March 28, 2020

Accepted: April 6, 2020

Published Online: April 7, 2020 https://doi.org/10.3126/jkahs.v3i1.28374 The DOI will be functional after the issue is fully published online as well as in printed version only. 


\section{INTRODUCTION}

The ongoing pandemic of COVID-19, a disease caused by a severe acute respiratory syndrome coronavirus 2 (SARS-CoV-2) was first detected as pneumonia of unknown etiology in Hubei province of China on December 2019. ${ }^{1,2}$ Initially COVID-19 patients were epidemiologically linked to the live seafood, animal, and bush-meat market in Wuhan, Hubei Province, China. ${ }^{3,4}$ During December 2019 only a few cases were reported but the rapid increase in infection was noted on the second half of January. Meanwhile, the infection reached outside Hubei Province due to the people's mobility for the Chinese New Year. ${ }^{5}$ Following the population movement, the outbreak also spread to other countries around the world. 6-9 The etiological agent responsible for this infection was not known in the beginning but at the end of December, it was identified as a novel coronavirus. ${ }^{10}$ Novel coronavirus was isolated on 7 January and the whole genome sequence was shared with the World Health Organization (WHO) on 12 January. On 11 February 2020, the International Committee on Taxonomy of Viruses (ICTV) names the virus as SARS-CoV-2 while the WHO named disease caused by this novel virus as COVID-19. ${ }^{11,12}$ On March 11, 2020, the WHO declared the COVID19 outbreak as a pandemic when the confirmed cases reached to 11,8319 with 4, 292 deaths worldwide. ${ }^{13,14}$ By 6 April 2020, there have been
1210956 confirmed cases of COVID-19 with 67594 deaths worldwide ${ }^{15}$

In the initial phase, it took more than three months for the confirmed cases to reach 100,000 globally as the major cases were imported with few followed by local transmission but as the community transmission was established, the cases doubled from 500,000 to a million in less than a week. In about three months, new cases in China have slowed its pace and many emergency hospitals made to treat COVID-19 have been closed down. Finally, authorities started allowing people to travel through to Wuhan City in Hubei province. South Korea, where a major outbreak began in February, has also seen its number of cases fall in the last couple of weeks. Countries like Italy, Spain and the US are still ramping up measures to try to slow down the spread of the virus. The US has more confirmed infections and deaths than any other country. ${ }^{16}$

\section{EPIDEMIOLOGY}

The etiological agent responsible for coronavirus disease 2019 (COVID-19) is SARS-CoV-2, a positive-sense RNA virus belonging to the family Coronaviridae. To date, there are seven known types of human coronaviruses. Four types (229E, NL63, OC43, and HKU1) are common and cause mild to moderate respiratory infections, like the common cold. Two types, Severe Acute Respiratory Syndrome coronavirus (SARS-CoV) and the Middle East Respiratory 
Syndrome coronavirus (MERS-CoV), can cause severe respiratory infections.

The genome sequence of this novel virus was $96 \%$ identical at the whole-genome level to a bat coronavirus and $79.6 \%$ identical to Severe acute respiratory syndrome coronavirus (SARSCoV). ${ }^{17}$ In 2003, SARS-CoV was responsible for 774 deaths worldwide with a case-fatality rate of 9.6 percent. ${ }^{18,19}$ This was followed by Middle East Respiratory Syndrome Coronavirus (MERS-CoV) in 2019 accounting for 856 deaths and a case-fatality rate of 34.4 percent, ${ }^{20}$ while the case-fatality rate of SARS-CoV-2 has been estimated to be 1.4 percent. ${ }^{21}$ Evidence of clusters of infected family members and medical workers confirmed the presence of human-tohuman transmission. ${ }^{6,22,} 23$ The main route of transmission of SARS-CoV-2 is respiratory droplet and close physical contact ${ }^{22-26}$ Droplet transmission may also occur through fomites in the immediate environment around the infected person. ${ }^{27}$ The mean incubation period has been noted to be about five days which could range from 1 to 14 days where ninety-five percent infected patients are more likely to experience symptoms within 11 to 12 days of contact. ${ }^{22,28,29}$ However, the asymptomatic carriers of SARSCoV-2 could have the incubation period of 19 days. This puts a challenge in containing the outbreak - where the possible contact is quarantined only for 14 days. ${ }^{30}$

\section{Case-fatality rate by Age group in different countries}

The case-fatality rate has been estimated in different countries based on their total number of death. Based on the reports provided of Chinese Center for Disease Control and Prevention on 17 February 2020, ${ }^{31}$ Viewpoint by Italian National Institute of Health on 17 March, ${ }^{32}$ and Korea Centers for Disease Control and Prevention on 3 April ${ }^{33}$ it has been concluded that the elderly population has a higher risk of mortality from COVID-19 (Figure 1). By these analyses, the case-fatality has been reported to be at $2.3 \%$ in China, $7.2 \%$ in Italy, 1.73\% in South Korea.

Multiple factors have influenced the case-fatality rate of COVID-19 across different countries and age groups. These factors range from a proportion of elderly population in the country, people living with comorbidities such as cardiovascular disease, diabetes, chronic respiratory disease, hypertension and cancer along with population with a higher rate of antibiotic resistance, and smoking habits. ${ }^{34,35}$ 
Figure 1: Case-fatality rate of COVID-19 by age among different countries

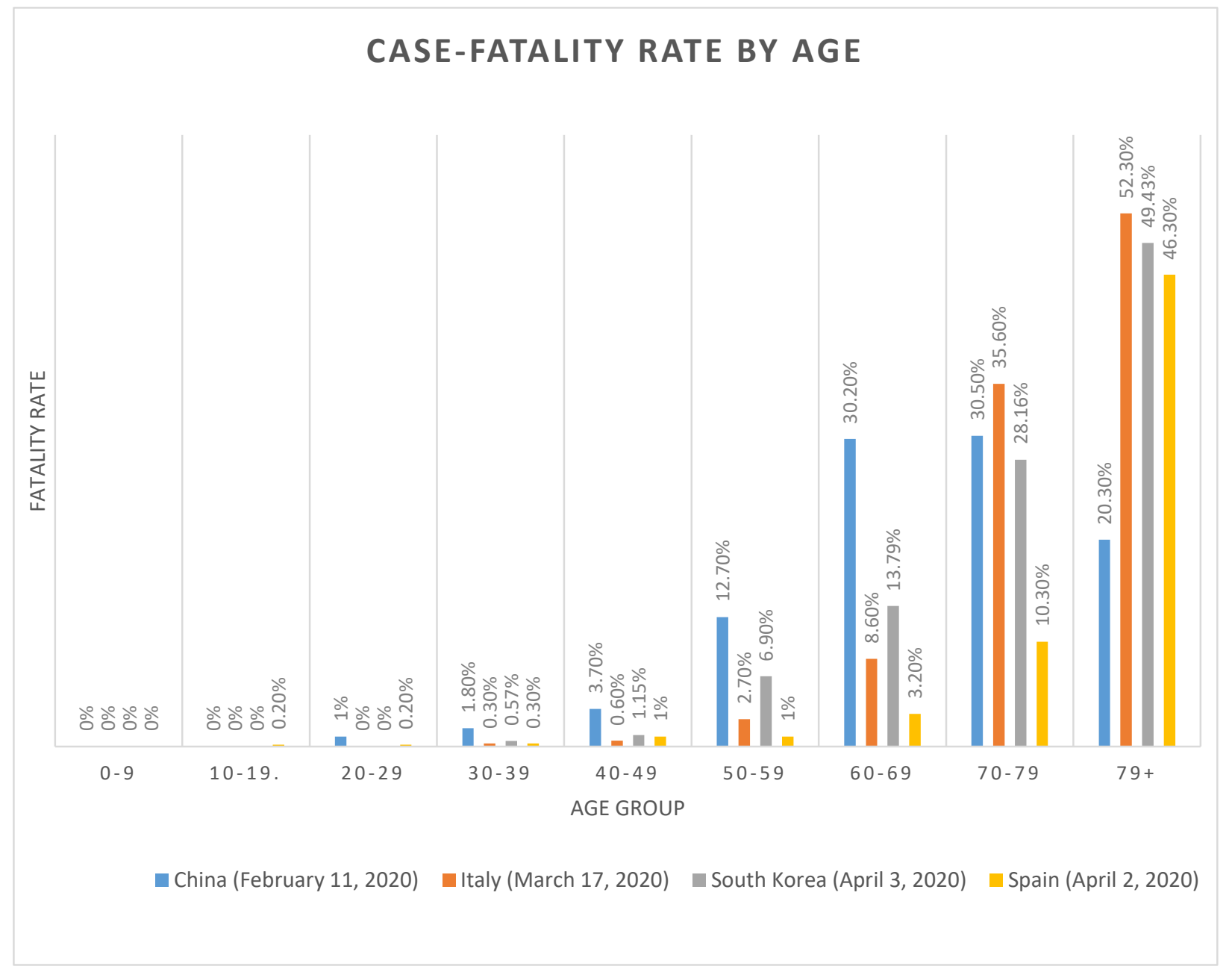

\section{GLOBAL RESPONSE TO COVID-19}

WHO has initiated the "Solidarity trial" to compare the safety and effectiveness of different drugs or drugs combination against COVID-19. By 27 March 2020, over seventy countries have committed to contribute to the trial. ${ }^{36,} 37$ Numerous antiviral compounds that are used to treat other infections are being clinically researched to find any possible treatment. Though multiple drugs are under clinical trials, it should be considered that in the absence of a concrete evidence, it might do more harm to the patient than benefiting them. ${ }^{38}$ In the context of COVID-19, the majority of the patients who died were elderly, people with cardiovascular disease, diabetes and other comorbidities. In these cases, the use of chloroquine/hydroxychloroquine, azithromycin, and lopinavir-ritonavir could potentially increase the risk of cardiac death. ${ }^{38}$

Although there have been multiple studies and trials, no effective vaccines or anti-viral treatments have been confirmed to be effective against SARS-CoV-2 infection and it has been estimated to take 12 to 18 months at minimum. ${ }^{37}$ 
In absence of any pharmaceutical intervention, the only strategy that seems to have worked so far for control of SARS-CoV-2 infection is to reduce the mixing of susceptible people through early identification of cases or reduction of contact. $^{39}$ If we take the example of different countries who have reduced the infection and those who are struggling to do so, it can be observed that the early detection of cases and community containment has been successful strategies. South Korea was able to lower the COVID-19 cases by an extensive and proactive community testing. Hundreds of thousands of people were tested for infection and the potential carriers were tracked at the initial phase of outbreak in the country. ${ }^{40}$ South Korea and Italy, both countries detected the first infection in late January but unlike South Korea, Italy accelerated its test only after March. By 2 April 2020, there have been a total of 9976 confirmed cases and 169 deaths in South Korea while Italy had 110574 confirmed cases with 13157 deaths. ${ }^{41}$ Epidemiologists suggest that it is not possible to compare the numbers directly but the dramatic difference in outcome points out that aggressive and sustained testing is a powerful tool for controlling the outbreak. ${ }^{40}$
In the initial phase of an outbreak due to delayed identification of the novel coronavirus and the population movement for lunar Chinese New Year there was a rapid growth in the number of infection in China till the first half of March. ${ }^{5}$ But as the epidemic was detected an estimated 40 to 60 million residents of Wuhan and 15 other closed cities were subjected to community containment measures. ${ }^{35}$ China took some aggressive measures including the closure of schools, workplaces, roads and transit systems, cancellation of public gatherings, mandatory quarantine of uninfected people without known exposure to COVID-19, and large-scale electronic surveillance to ensure compliance. ${ }^{42,43}$ These traditional strategies of isolation, quarantine, social distancing and community containment helped China to hold its level of infection after the second half of March 2020. Similarly, due to extensive testing during February before the major outbreaks, South Korea was successful to limit the infection at a minimum. Moreover, with the increasing number of cases, Italy, United State and the United Kingdom increased its testing facilities. 


\section{Total tests for COVID-19 per million people}

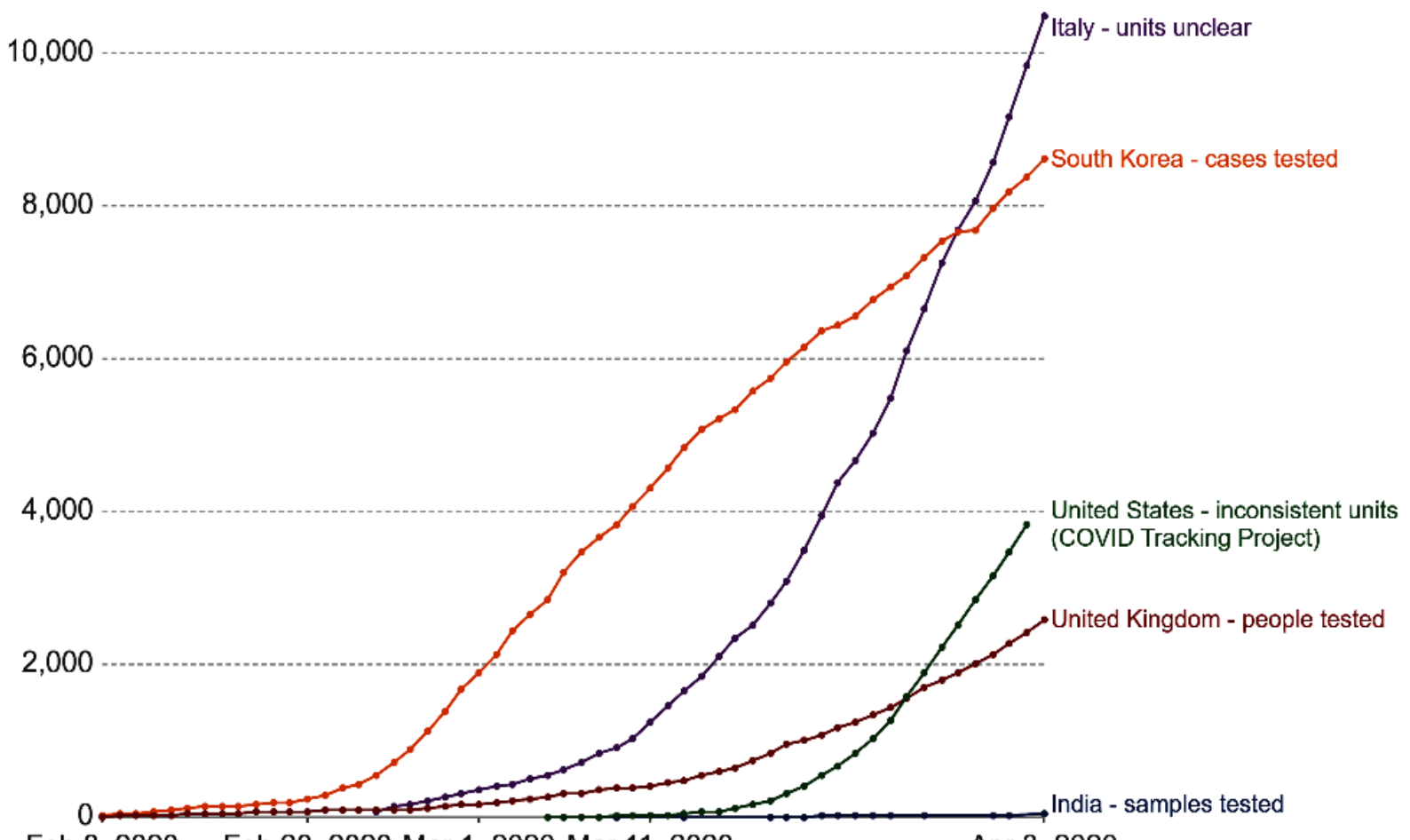

Feb 8, 2020 Feb 20, 2020 Mar 1, 2020 Mar 11, 2020

Apr 3, 2020

Source: Official sources collated by Our World in Data

OurWorldlnData.org/coronavirus • CC BY Note: There are substantial differences across countries in terms of the units, whether or not all labs are included, the extent to which negative and pending tests are included and other aspects. Details for each country can be found at ourworldindata.org/covid-testing.

Figure 2: Total tests for COVID-19 per million population in different countries

\begin{tabular}{|c|c|c|c|c|}
\hline & China & South Korea & Italy & African Nations \\
\hline $\begin{array}{l}\text { Major } \\
\text { Response }\end{array}$ & $\begin{array}{l}\text { Forced quarantine of mass } \\
\text { population with a major } \\
\text { lockdown in the initial } \\
\text { stage which lasted until the } \\
\text { infection rate declined } \\
\text { drastically. All the } \\
\text { suspected cases were } \\
\text { isolated and all the patients } \\
\text { were admitted for } \\
\text { treatment. Massive } \\
\text { sanitation measures were } \\
\text { also applied. }\end{array}$ & $\begin{array}{l}\text { Massive screening of the } \\
\text { population to prevent mixing of } \\
\text { suspected/ infected population } \\
\text { with the health community in } \\
\text { the initial stage of outbreak } \\
\text { along with other community } \\
\text { containment and awareness } \\
\text { measures without a lockdown } \\
\text { such as the closure of schools } \\
\text { and public gathering, use of } \\
\text { masks and mass sanitization } \\
\text { along with health message } \\
\text { through different media. }\end{array}$ & $\begin{array}{l}\text { Control of mass } \\
\text { gathering with a } \\
\text { lockdown but it } \\
\text { delayed the screening } \\
\text { measures though the } \\
\text { initial infections were } \\
\text { detected at the same } \\
\text { duration as of South } \\
\text { Korea }\end{array}$ & $\begin{array}{l}\text { Strong border } \\
\text { protection, flight } \\
\text { restriction and } \\
\text { quarantine to the } \\
\text { foreigners along with } \\
\text { control of mass } \\
\text { gathering with the } \\
\text { closure of school and } \\
\text { promotion of hand } \\
\text { sanitization }\end{array}$ \\
\hline
\end{tabular}




\begin{tabular}{|c|c|c|c|c|}
\hline Result & $\begin{array}{l}\text { Lowered the infection } \\
\text { within the three-month } \\
\text { duration }\end{array}$ & Rapidly, lower the infection rate & $\begin{array}{l}\text { High infection and } \\
\text { mortality } \quad \text { was } \\
\text { accounted a month of } \\
\text { time }\end{array}$ & $\begin{array}{l}\text { Lowered the rate of } \\
\text { infection in comparison } \\
\text { to other developed } \\
\text { nations }\end{array}$ \\
\hline $\begin{array}{l}\text { Pressure } \\
\text { to the } \\
\text { health } \\
\text { system }\end{array}$ & $\begin{array}{l}\text { Maximized in the initial } \\
\text { phase as the cause was not } \\
\text { detected and the outbreak } \\
\text { was peaked but minimized } \\
\text { as the major focus given on } \\
\text { prevention approach }\end{array}$ & $\begin{array}{l}\text { Maximized in the initial phase } \\
\text { as it focuses on test, screening } \\
\text { and treatment which helped to } \\
\text { lower the curve and at the end } \\
\text { reduced burden to health care }\end{array}$ & $\begin{array}{l}\text { Maximized the total } \\
\text { health care cost and } \\
\text { burden to the system } \\
\text { as the hospital were } \\
\text { overflowed with cases }\end{array}$ & $\begin{array}{l}\text { Minimized the pressure } \\
\text { to the health system by } \\
\text { reducing the number of } \\
\text { cases }\end{array}$ \\
\hline $\begin{array}{l}\text { Effect to } \\
\text { National } \\
\text { economy }\end{array}$ & $\begin{array}{l}\text { In the initial phase due to } \\
\text { the complete lockdown, it } \\
\text { impacted largely to the } \\
\text { national economy along } \\
\text { with great loss of life's }\end{array}$ & $\begin{array}{l}\text { As there was no lockdown, and } \\
\text { fewer cases and mortality than } \\
\text { others the impact to the national } \\
\text { economy wasn't as much as } \\
\text { other nations }\end{array}$ & $\begin{array}{l}\text { Due to the high } \\
\text { burden of cases, } \\
\text { mortality and } \\
\text { lockdown the } \\
\text { economy was highly } \\
\text { affected }\end{array}$ & $\begin{array}{l}\text { It impacted on aid } \\
\text { development works } \\
\text { carried out by foreign } \\
\text { personnel and } \\
\text { organization as the } \\
\text { travel of foreigners as } \\
\text { restricted }\end{array}$ \\
\hline
\end{tabular}

\section{Total confirmed COVID-19 cases}

The number of confirmed cases is lower than the number of total cases. The main reason for this is limited testing.

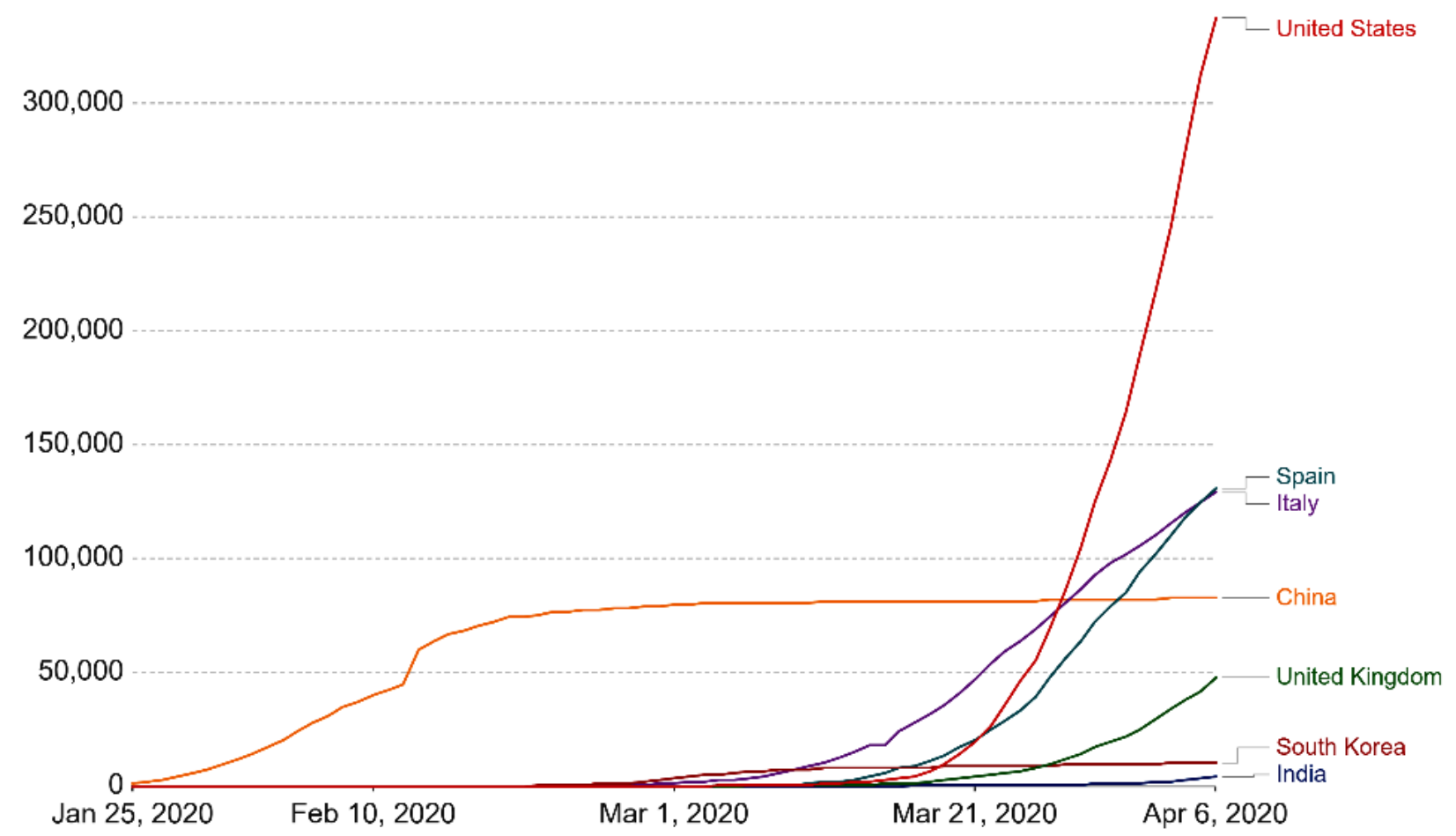

Source: European CDC - Situation Update Worldwide - Last updated 6th April, 12:00 (London time) OurWorldInData.org/coronavirus • CC BY Note: The large increase in the number of cases globally and in China on Feb 13 is the result of a change in reporting methodology.

Figure 3: Total confirmed cases of COVID-19 in different countries till 4 April 2020 In summary 


\section{NEPAL'S POSITION IN THE PANDEMIC}

Despite being a neighbor country to China, where the outbreak was initially detected, By 6 April 2020, only 1890 tests have been performed in the suspected cases of with nine positive cases were identified.$^{44}$ Of these nine cases, the first case was detected on 25 January in a 32-year-old student who returned from the Wuhan University of Technology and by the end of January, he was reported to be cured. ${ }^{45}$ Five of the other cases were detected after two months. All the infections detected were the imported cases. On 4 April 2020 an additional three cases were identified with one suspected to have local transmission.

\section{CASE DESCRIPTION OF NEPAL}

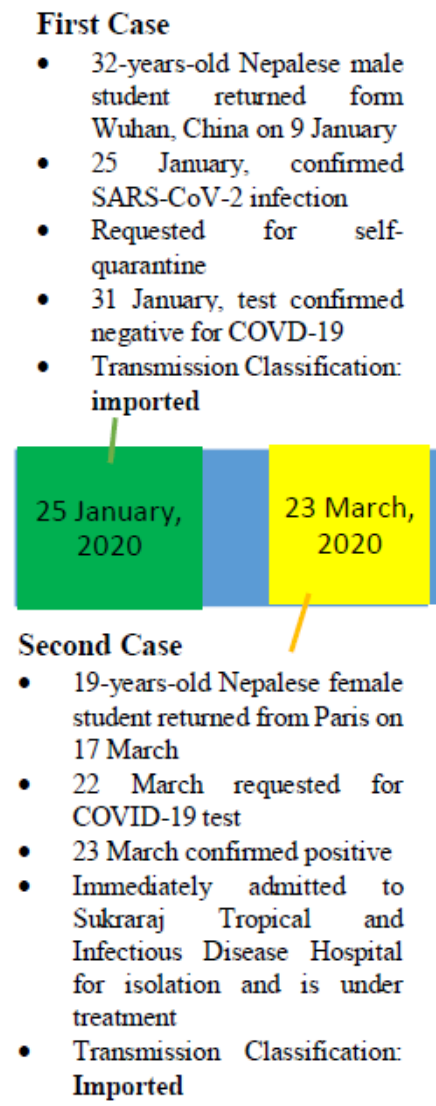

\section{Third Case}

- 19 March, 32-years-old male returned from Dubai

- 23 March, went to Sukraraj Tropical and Infectious Disease Hospital as he felt unwell

- 25 March, diagnosed with COVID-19

- Under treatment

- Transmission Classification Imported
Fifth Case

- 17 March 19-years-old female student, returned from Belgium

- Experienced some symptoms and went for testing

- $28 \mathrm{March}$ she was tested positive for COVID-19 by NPHL

- On her refusal to stay in hospital, she was asked to be in self-quarantine

- Undergoing treatment in isolation

$\bullet$ Transmission Classification Imported
Seventh and Eight Case

21-years-old male from Kailali returned from Mumbai, India

41-year-old male from Kanchanpur returned form Uttarkhanda, India

- Both stayed in some form of quarantine before getting diagnosed

- Transmission Classification: Imported

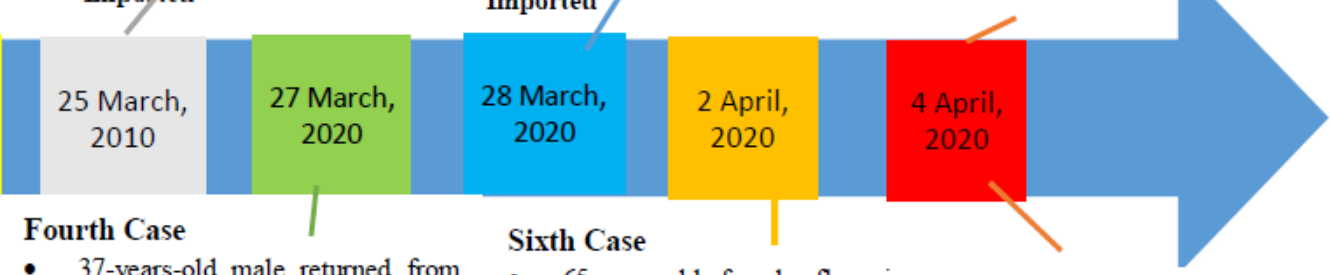

- 37-years-old male returned from Dubai with a transit in Delhi

- 20 March, arrived in Kathmandu after spending six-hour transit in Delhi while returning from Dubai in Emeritus Airlines

- 27 March, NPHL tested him positive for COVID-19

- $\mathrm{He}$ is under treatment at Seti Provincial Hospital in Dhanghadi

- Transmission Classification: Imported
- 65-years-old female flew in same Qatar Airway flight from Belgium along with case no. 5 .

- When case no. 5 was diagnosed with COVID-19, she finally went into self-isolation.

- April 2 confirmed positive for COVID-19

- Under treatment

- Transmission Classification Imported

\section{Ninth case}

- 34-year-old woman from Kailali tested positive for COVID-19

- First case of local transmission in Nepal as it is assumed that the infection was acquired from case no. 4

- Transmission Classification: Local

Figure 4: Nepal's COVID-19 cases description

Though the case was identified in January, the country-wide lockdown came into effect on 24 March under Article 2 of the Contagious Disease Act, 2020 (1953). ${ }^{46}$ In the initial phase, Nepal failed to capture the significance of this global problem as not much was done to prevent it. On
17 January, WHO urged the Government of Nepal to screen the people arriving from China, Thailand and Japan at the Tribhuvan International Airport as these were the countries with the higher cases. Nepal established healthdesks at the international airport as well as on the 
border checkpoints in the second half of January. Nepal has a weaker health system, it lacks adequate diagnostic facilities, there are very few hospitals with proper resources to handle infectious diseases, isolation wards and ICU facilities alongside not enough competent human resources and enough personal protective equipment (PPE) to protect the health workforce. $^{45,47-50}$ In this scenario, it is clear that the country was not able to handle the infection without any external support in case of outbursts so the major focus should have been given to preventive measures through proper screening at the international airports and trade borders.

By the middle of March, the Nepal government announced the suspension of visa-on-arrival services for all countries. ${ }^{46,51}$ On 20 March the government took some aggressive measures such as the government banned all the passengers from Europe, United Kingdom, West Asia and the Middle East. ${ }^{52}$ All places of public gathering were banned along with the gathering restriction on 25 people in any public space. On 23 March, Nepal closed its land border with India and China and was followed by countrywide lockdown on 24 March 2020. ${ }^{53}$ Based on the report provided by National Emergency Operation Center (NEOC) under Ministry of Health and Population, Nepal is trying its best to increase the number of isolation and quarantine facilities along with the provision of essential PPE. By 5 April 2020, throughout the country 30566 beds has been allocated for quarantine facilities while only 9168 bed has been assigned for isolation with 6795 PPE Gown distributed to all province excluding the hospital inside Kathmandu Valley.

Table 1: List of allocated quarantine, isolation and PPE facilities among different province of Nepal until 5 April 2020

\begin{tabular}{|c|c|c|c|c|c|}
\hline Province & $\begin{array}{l}\text { Number of beds } \\
\text { for Quarantine }\end{array}$ & $\begin{array}{l}\text { Number of people } \\
\text { under Quarantine }\end{array}$ & $\begin{array}{l}\text { Number of } \\
\text { beds for } \\
\text { Isolation }\end{array}$ & $\begin{array}{l}\text { Number of } \\
\text { People } \\
\text { under } \\
\text { Isolation }\end{array}$ & $\begin{array}{l}\text { Number of PPE } \\
\text { Gown } \\
\text { distributed }\end{array}$ \\
\hline Province 1 & 4147 & 898 & 438 & 13 & 1358 \\
\hline Province 2 & 3239 & 917 & 328 & 27 & 693 \\
\hline Bagmati Province & 4214 & 727 & 828 & 26 & 663 \\
\hline Gandaki Province & 4522 & 947 & 378 & 8 & 942 \\
\hline Province 5 & 5740 & 2600 & 526 & 16 & 1051 \\
\hline Karnali Province & 3666 & 743 & 520 & 0 & 1218 \\
\hline Sudurpashchim Province & 5038 & 2336 & 246 & 5 & 161 \\
\hline Total & 30566 & 9168 & 3259 & 95 & 6795 \\
\hline
\end{tabular}




\section{NEPAL'S CHALLENGES}

COVID-19 outbreak is spreading worldwide, posing an enormous threat to life and health and bringing a formidable challenge to global public health security. Sooner the cases are detected, isolated, and tracked, the more successful the prevention strategies will be. Nepal is at stage II of a pandemic but it is difficult to say how the disease is circulating in our population. The projection on COVID-19 by Neupane et.al ${ }^{54}$ illustrates that if this problem is not properly mitigated the effects could be catastrophic. Even US experts acknowledged that they didn't know their status during early March so they experienced the horrible situation at the moment. ${ }^{55}$ Nepal being, blindfolded is not very unusual due to our weak surveillance system. At least Nepal could have collected PPE and manage testing within the last eleven weeks since the first case was detected but it was not done. ${ }^{45}$ Lockdown is the blanket approach which buys us time period to apply other strong public health measures such as active case finding, quarantine,

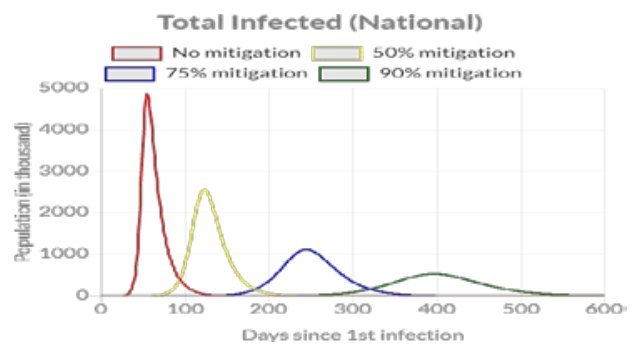

Figure 5: COVID-19 Projection for Nepal by Neupane et.al ${ }^{54}$ CONCLUSION isolation and treatment. ${ }^{44}$ Nepal need to be very proactive in this regard otherwise once the country experiences increased cases it will be too late and we can't blame the virus and blame each other. Politically, Nepal has developed federal networks with elected representatives from local to provincial and up to the federal level. What is lacking is the close coordination between these tiers of governance and lack of intersectional collaboration. ${ }^{45,56}$ The health sector alone cannot address such a big outbreak and the role of other sectors such as agriculture, education, supplies, transport, and local development organizations are also equally important. Both sectors from health and general public need to work together in this situation but the pragmatic steps and way forward have not been translated in reality. There is a need to expand community engagement ${ }^{57-59}$ and continue trace, test and treat strategies and empower the frontline health workforce with skills and necessary supplies to cater patient-care and ensure protection of service providers as well. ${ }^{60,61}$

While the scientific world continues to look for possible drugs and vaccines, developing nation 
such as Nepal remains with public health measures which have been proven to be highly effective at curbing the epidemics such as in Taiwan, South Korea and Singapore. At this crucial moment, social distancing is the best possible prevention measure to contain the COVID-19 disease but it cannot stand alone. Bold political choices can save lives, and they must be taken preemptively. There is a need to initiate a stringent mechanism to operate the measures including conducting proactive testing, strengthening the supply chain logistics for health care workers, and establishing temporary (or re-strengthening) ICU facilities and

\section{REFERENCES}

1. Wuhan Municipal Health Commission. Report of clustering pneumonia of unknown etiology in Wuhan City. Wuhan Municipal Health Commission: Wuhan City health committee; 2019. [Link]

2. World Health Organization. Pneumonia of unknown cause - China, Disease outbreak news 2020. [Link]

3. Bogoch II, Watts A, Thomas-Bachli A, Huber C, Kraemer MUG, Khan K. Pneumonia of unknown aetiology in Wuhan, China: potential for international spread via commercial air travel. Journal of Travel Medicine. 2020;27(2). [PubMed] [PMC Full text]

4. Lu H, Stratton CW, Tang Y-W. Outbreak of pneumonia of unknown etiology in Wuhan, China: The mystery and the miracle. Journal of Medical Virology. 2020;92(4):401-2. [PubMed]

5. $\quad$ Yang Y, Lu Q, Liu M, Wang Y, Zhang A, Jalali N, et al. Epidemiological and clinical features of the 2019 novel coronavirus outbreak in China. medRxiv. 2020:2020.02.10.20021675. [Link]

6. World Health Organization. Statement on the second meeting of the International Health Regulations (2005) Emergency Committee regarding the outbreak of novel coronavirus (2019-nCoV) 2020. [Link] allocating spaces for quarantine and isolation. The most important step for Nepal now is to immediately start the proactive community testing. The more we do the test, the more we know the cases to be isolated which can help us to prevent the community transmission. For the general public, cooperation in regards to government's measures are absolutely vital. The important being strictly adhering to the social distancing strategy in addition to helping the community to identify the suspected cases, and endorsing for testing and self-quarantine for anyone with symptoms.

7. Holshue ML, DeBolt C, Lindquist S, Lofy $\mathrm{KH}$, Wiesman J, Bruce H, et al. First Case of 2019 Novel Coronavirus in the United States. The New England journal of medicine. 2020;382(10):929-36. [PubMed]

8. Phan LT, Nguyen TV, Luong QC, Nguyen TV, Nguyen HT, Le HQ, et al. Importation and Humanto-Human Transmission of a Novel Coronavirus in Vietnam. 2020;382(9):872-4. [PubMed]

9. Giovanetti M, Benvenuto D, Angeletti S, Ciccozzi M. The first two cases of 2019-nCoV in Italy: Where they come from? Journal of Medical Virology. 2020;92(5):518-21. [PubMed]

10. World Health Organization. WHO Statement regarding cluster of pneumonia cases in Wuhan, China 2020.[Link]

11. World Health Organization. Naming the coronavirus disease (COVID-19) and the virus that causes it. [Link]

12. Gorbalenya AE, Baker SC, Baric RS, de Groot RJ, Drosten C, Gulyaeva AA, et al. The species Severe acute respiratory syndrome-related coronavirus: classifying 2019-nCoV and naming it SARS-CoV2. Nature Microbiology. 2020;5(4):536-44. [PubMed]

13. World Health Organization. WHO announces COVID-19 outbreak a pandemic 2020. [Link] 
14. WHO. Coronavirus disease 2019 (COVID-19) Situation Report - 51 2020. [Link]

15. WHO. Coronavirus disease 2019 (COVID-19) Situation Report - 74 2020. [Link]

16. WHO. World Health Organization. Coronavirus disease (COVID-2019) situation reports 2020. [Link]

17. Zhou P, Yang X-L, Wang X-G, Hu B, Zhang L, Zhang $\mathrm{W}$, et al. A pneumonia outbreak associated with a new coronavirus of probable bat origin. Nature. 2020;579(7798):270-3. [PubMed]

18. Peiris JS, Guan Y, Yuen KY. Severe acute respiratory syndrome. Nature medicine. 2004;10(12 Suppl):S88-97. [PubMed]

19. World Health Organization. Summary of probable SARS cases with onset of illness from 1 November 2002 to 31 July 2003. [Link]

20. World Health Organization. Middle East respiratory syndrome coronavirus (MERS-CoV). 2019. [Link].

21. Verity R, Okell LC, Dorigatti I, Winskill P, Whittaker C, Imai N, et al. Estimates of the severity of coronavirus disease 2019: a model-based analysis. The Lancet Infectious Diseases. [Link]

22. Li Q, Guan X, Wu P, Wang X, Zhou L, Tong Y, et al. Early Transmission Dynamics in Wuhan, China, of Novel Coronavirus-Infected Pneumonia. New England Journal of Medicine. 2020;382(13):1199207. [PubMed]

23. Chan JF, Yuan S, Kok KH, To KK, Chu H, Yang J, et al. A familial cluster of pneumonia associated with the 2019 novel coronavirus indicating personto-person transmission: a study of a family cluster. Lancet (London, England). 2020;395(10223):51423. [PubMed]

24. Jiaye L, Xuejiao L, Shen Q, Jing Y, Fuxiang W, Yingxia L, et al. Community Transmission of Severe Acute Respiratory Syndrome Coronavirus 2, Shenzhen, China, 2020. Emerging Infectious Disease journal. 2020;26(6). [Link]

25. Huang C, Wang Y, Li X, Ren L, Zhao J, Hu Y, et al. Clinical features of patients infected with 2019 novel coronavirus in Wuhan, China. Lancet (London, England). 2020;395(10223):497-506. [PubMed]

26. Burke RM, Midgley CM, Dratch A, Fenstersheib M, Haupt T, Holshue M, et al. Active Monitoring of Persons Exposed to Patients with Confirmed COVID-19 - United States, January-February 2020. MMWR Morbidity and mortality weekly report. 2020;69(9):245-6. [Link]

27. Ong SWX, Tan YK, Chia PY, Lee TH, Ng OT, Wong MSY, et al. Air, Surface Environmental, and Personal Protective Equipment Contamination by Severe Acute Respiratory Syndrome Coronavirus 2 (SARS-CoV-2) From a Symptomatic Patient. JAMA. 2020. [PubMed]

28. Wang D, Hu B, Hu C, Zhu F, Liu X, Zhang J, et al. Clinical Characteristics of 138 Hospitalized Patients
With 2019 Novel Coronavirus-Infected Pneumonia in Wuhan, China. JAMA. 2020;323(11):1061-9. [PubMed]

29. Lauer SA, Grantz KH, Bi Q, Jones FK, Zheng Q, Meredith HR, et al. The Incubation Period of Coronavirus Disease 2019 (COVID-19) From Publicly Reported Confirmed Cases: Estimation and Application. Annals of Internal Medicine. 2020. [PubMed]

30. Bai Y, Yao L, Wei T, Tian F, Jin D-Y, Chen L, et al. Presumed Asymptomatic Carrier Transmission of COVID-19. JAMA. 2020. [PubMed]

31. The epidemiological characteristics of an outbreak of 2019 novel coronavirus diseases (COVID-19) in China. Zhonghua liu xing bing xue za zhii. 2020;41(2):145-51. [PubMed]

32. Onder G, Rezza G, Brusaferro S. Case-Fatality Rate and Characteristics of Patients Dying in Relation to COVID-19 in Italy. JAMA. 2020. [PubMed]

33. KDC. Press Release: The updates on COVID-19 in Korea as of 3 April: Division of Risk assessment and International cooperation; 2020. [Link]

34. Oke J, Heneghan C. Oxford COVID-19 Evidence Service: Global Covid-19 Case Fatality Rates 2020. [Link]

35. Wu Z, McGoogan JM. Characteristics of and Important Lessons From the Coronavirus Disease 2019 (COVID-19) Outbreak in China: Summary of a Report of 72314 Cases From the Chinese Center for Disease Control and Prevention. JAMA. 2020. [PubMed]

36. Kalil AC. Treating COVID-19-Off-Label Drug Use, Compassionate Use, and Randomized Clinical Trials During Pandemics. JAMA. 2020. [PubMed]

37. Cheng MP, Lee TCL, Tan DHS, Murthy S. Generating randomized trial evidence to optimize treatment in the COVID-19 pandemic. Canadian Medical Association Journal. 2020:cmaj.200438. [Link]

38. World Health Organization. WHO DirectorGeneral's opening remarks at the media briefing on COVID-19 - 27 March 2020. [Link]

39. Lewnard JA, Lo NC. Scientific and ethical basis for social-distancing interventions against COVID-19. 2020. [PubMed]

40. Emilio Parodi, Stephen Jewkes, Sangmi Cha, Park Jm. Special Report: Italy and South Korea virus outbreaks reveal disparity in deaths and tactics. Reuters. 2020. [Link]

41. World Health Organization. Coronavirus disease 2019 (COVID-19) Situation Report - 702020. [Link]

42. McCloskey B, Heymann DL. SARS to novel coronavirus - old lessons and new lessons. Epidemiology and infection. 2020;148:e22. [PubMed] 
43. Wilder-Smith A, Freedman DO. Isolation, quarantine, social distancing and community containment: pivotal role for old-style public health measures in the novel coronavirus (2019-nCoV) outbreak. J Travel Med. 2020;27(2). [PubMed]

44. MOHP. Government of Nepal. Ministry of Health and Population, Nepal's latest Update on COVID-19 2020. [Link]

45. Bastola A, Sah R, Rodriguez-Morales AJ, Lal BK, Jha R, Ojha HC, et al. The first 2019 novel coronavirus case in Nepal. The Lancet Infectious Diseases. 2020;20(3):279-80. [PubMed]

46. MOFA. Government of Nepal. Ministry of Foreigh Affairs. Decision of HLCC for the Prevention and Control of COVID-19 on 25 March 2020 and Unofficial Translation 2020. [Link]

47. Pokharel S, Raut S, Adhikari B. Tackling antimicrobial resistance in low-income and middleincome countries. BMJ Global Health. 2019;4(6):e002104. [PubMed]

48. Sapkota R. Protecting those who protect us from the epidemic. Hospital staff in Nepal at the frontlines of the battle against COVID-19 lack protective gear: Times Nepal; 2020. Link]

49. Adhikari B, Mishra SR, Babu Marahatta S, Kaehler N, Paudel K, Adhikari J, et al. Earthquakes, Fuel Crisis, Power Outages, and Health Care in Nepal: Implications for the Future. Disaster Med Public Health Prep. 2017;11(5):625-32. [PubMed]

50. Marahatta SB, Yadav RK, Giri D, Lama S, Rijal KR, Mishra SR, et al. Barriers in the access, diagnosis and treatment completion for tuberculosis patients in central and western Nepal: A qualitative study among patients, community members and health care workers. PLoS One. 2020;15(1):e0227293. [PubMed]

51. Xinhua. Nepal suspends visa-on-arrival for nationals of countries badly affected by COVID-19. ASIA\&PACIFIC. 2020. [Link]
52. Prasain S, Shrestha PM. The Kathmandu Post: Government bans entry of all passengers, including Nepalis, from midnight March 2020 2020. . [Link]

53. Pradhan TR. The Kathmandu Post: Government to close down border with India and China for a week. 2020. [Link]

54. Neupane D, Adhikari B, Dahal V, Pathak S. Covid19 Projections for Nepal 2020. [Link]

55. Brown E, Reinhard B, Davis AC. Coronavirus death toll: Americans are almost certainly dying of covid19 but being left out of the official count. The Washington Post. 2020. [Link]

56. Amgain K, Neupane S, Panthi L. Myths vs. Truths regarding the Novel Coronavirus Disease (COIV2019) Outbreak. Journal of Karnali Academy of Health Sciences. 2020;3(1):1-6. [Link]

57. Adhikari B, James N, Newby G, von Seidlein L, White NJ, Day NP, et al. Community engagement and population coverage in mass anti-malarial administrations: a systematic literature review. Malaria journal. 2016;15(1):523. [PubMed]

58. Adhikari B, Pell C, Phommasone K, Soundala X, Kommarasy P, Pongvongsa T, et al. Elements of effective community engagement: lessons from a targeted malaria elimination study in Lao PDR (Laos). Glob Health Action. 2017;10(1):1366136. [PubMed]

59. Adhikari B, Mishra SR, Raut S. Rebuilding Earthquake Struck Nepal through Community Engagement. Frontiers in public health. 2016;4:121. [PubMed]

60. Guardian T. WHO urges countries to 'track and trace' every Covid-19 case.2020. [Link]

61. Sajed AN, Amgain K. Corona Virus Disease (COVID-19) Outbreak and the Strategy for Prevention. Europasian J. of Med. Sci. [Internet]. 2020;2(1):1-.5. [Link] 